\title{
CHAPTERS AND BOOKS
}

1. Weinreb, S.M. "Evolution of a Strategy for Total Synthesis of Streptonigrin," in Strategies and Tactics of Organic Synthesis; Lindberg, T., Ed.; Academic Press: San Diego, 1984, pp. 325-345.

2. Boger, D.L; Weinreb, S.M. Hetero Diels-Alder Methodology in Organic Synthesis; Academic Press: San Diego, 1987.

3. Franck, R.W.; Weinreb, S.M. "The Aureolic Acid Antitumor Antibiotics: A Challenge for Organic Synthesis," in Studies in Natural Products Chemistry; Rahman, A., Ed.; Elsevier Science Publishers: Amsterdam, 1989, Vol. 3 (Part B), pp. 173-207.

4. Weinreb, S.M. "Heterodienophile Additions to Dienes," in Comprehensive Organic Synthesis; Trost, B.M., Fleming, I., Eds.; Pergamon Press: Oxford, 1991, Vol. 5, pp. 401-449.

5. Weinreb, S.M.; Henry, J.R. " $N$-( $t$-Butoxycarbonyl)-p-toluenesulfonamide," in Encyclopedia of Reagents for Organic Synthesis; Paquette, L.A., Ed.; Wiley: Chichester, U.K., 1995, Vol. 2, pp. 842-843.

6. Weinreb, S.M.; Ralbovsky, J.L. " " 3 -Trimethylsilylethanesulfonyl Chloride," in Encyclopedia of Reagents for Organic Synthesis; Paquette, L.A., Ed.; Wiley: Chichester, U.K., 1995, Vol. 7, pp. $5255-5256$.

7. Weinreb, S.M.; Herr, R.J. "N-Butyl $N$-(p-Toluenesulfonyl)iminoacetate," in Encyclopedia of Reagents for Organic Synthesis; Paquette, L.A., Ed.; Wiley: Chichester, U.K., 1995, Vol. 2, pp. 944-947.

8. Weinreb, S.M.; Borzilleri, R.M. "N-Sulfinyl-p-toluenesulfonamide," in Encyclopedia of Reagents for Organic Synthesis; Paquette, L.A., Ed.; Wiley: Chichester, U.K., 1995, Vol. 7, pp. 4676-4678.

9. Weinreb, S.M.; Folmer, J.J. "N,O-Dimethylhydroxylamine," in Encyclopedia of Reagents for Organic Synthesis; Paquette, L.A., Ed.; Wiley: Chichester, U.K., 1995, Vol. 3, pp. 2083-2086.

10. Weinreb, S.M.; Anderson, G.T.; Nylund, C.S. "Dimethylaluminum Amide," in Encyclopedia of Reagents for Organic Synthesis; Paquette, L.A., Ed.; Wiley: Chichester, U.K., 1995, Vol. 3, pp. 1997-2001.

11. Weinreb, S.M.; Heintzelman, G.R. "Bis[N-(p-toluenesulfonyl)]selenodiimide," in Encyclopedia of Reagents for Organic Synthesis; Paquette, L.A., Ed.; Wiley: Chichester, U.K., 1995, Vol. 1, pp. 562-564.

12. Weinreb, S.M.; Borzilleri, R.M. "Bis[N-(p-toluenesulfonyl)]sulfodiimide," in Encyclopedia of Reagents for Organic Synthesis; Paquette, L.A., Ed.; Wiley: Chichester, U.K., 1995, Vol. 1, pp. 564-567.

13. Weinreb, S.M. "Total Synthesis of the Microbial Antitumor Antibiotics Actinobolin and Bactobolin" in Studies in Natural Products Chemistry; Rahman, A., Ed.; Elsevier Science 
Publishers: Amsterdam, 1995, Vol. 16 (Part J), pp. 3-25.

14. Garigipati, R.S.; Weinreb, S.M. "1,2-Thiazines and Their Benzo Derivatives" in Comprehensive Heterocyclic Chemistry II; Katritzky, A.R., Rees, C.W., Scriven, E.F.V., Eds.; Pergamon Press: Oxford, 1996, Vol. 6, pp. 349-382.

15. Weinreb, S.M.; Bebbington, M.W.P. "Allyl(2-chloroethyl)dimethylsilane" in Electronic Encyclopedia of Reagents for Organic Synthesis; Paquette, L.A., Ed.; Wiley: Chichester, U.K., 2003.

16. Weinreb, S.M.; Mahajan, Y.R. "Introduction" in Science of Synthesis, Houben-Weyl Methods of MolecularTransformations; Weinreb, S.M., Ed.; Thieme: Stuttgart, 2003; Vol. 17, pp. 1-18.

17. Weinreb, S.M.; Bebbington, M.W.P. "Bis( $\beta$-trimethylsilylethanesulfonyl)imide" in Electronic Encyclopedia of Reagents for Organic Synthesis; Paquette, L.A., Ed.; Wiley: Chichester, U.K., 2004.

18. Weinreb, S.M.; Bebbington, M.W.P. " $\beta$-Tosylethylhydrazine" in Electronic Encyclopedia of Reagents for Organic Synthesis; Paquette, L.A., Ed.; Wiley: Chichester, U.K., 2004.

19. Weinreb, S.M.; Artman, G.D., III " $\beta$-Tosylethylhydroxylamine" in Electronic Encyclopedia of Reagents for Organic Synthesis; Paquette, L.A., Ed.; Wiley: Chichester, U.K., 2004.

20. Weinreb, S.M.; Artman, G.D., III " $\beta$-Tosylethylamine" in Electronic Encyclopedia of Reagents for Organic Synthesis; Paquette, L.A., Ed.; Wiley: Chichester, U.K., 2004.

21. Mahajan, Y.R.; Weinreb, S.M. "Introduction" in Science of Synthesis, Houben-Weyl Methods of MolecularTransformations; Weinreb, S.M., Ed; Thieme: Stuttgart, 2005; Vol. 21, pp. 1-15.

22. Mahajan, Y.R.; Weinreb, S.M. "21.1 Introduction and Overview of General Methods for Synthesis of Amides" in Science of Synthesis, Houben-Weyl Methods of MolecularTransformations; Weinreb, S.M., Ed.; Thieme: Stuttgart, 2005; Vol. 21, pp. 17-25.

23. Weinreb, S.M.; Borstnik, K. "2-Propanone Oxime" in Electronic Encyclopedia of Reagents for Organic Synthesis; Paquette, L.A.; Fuchs, P.L.; Crich, D.; Molander, G.A., Eds.; Wiley: Chichester, U.K., 2006.

24. Weinreb, S.M.; Seo, J.H. " $\beta$-Tosylethylazide" in Electronic Encyclopedia of Reagents for Organic Synthesis; Paquette, L.A.; Fuchs, P.L.; Crich, D.; Molander, G.A., Eds.; Wiley: Chichester, U.K., 2006.

25. Orr, R.K.; Weinreb, S.M. "1,2-Thiazines and Their Benzo Derivatives" in Comprehensive Heterocyclic Chemistry III; Katritzky, A.R.; Taylor, R.; Rasmsden, C.A.; Scriven, E.F.V., Eds.; Elsevier: Oxford, 2008, Vol. 7, p. 000-000. 